\title{
Analisis Kadar Trigliserida Dan HDL (High Density Lipoprotein) Pada Tenaga Farmasi Di Apotek Indobat Denpasar
}

\author{
A.A. Sagung Mas Indrayani*, Ni Putu Rahayu Artini*, I Wayan Tanjung Aryasa* \\ *Program Studi Teknologi Laboratorium Medik, Institut Ilmu Kesehatan Medika Persada Bali \\ Email : anjellchuuwa@gmail.com
}

\begin{abstract}
Tanggal Submit:

28 Januari 2019

Tanggal Review:

03 Mei 2019

Tanggal Publish

Online:

19 September 2019

Night shift can cause health problems one of which is the body's circadian rhythm disturbance which can lead to increased triglyceride levels and decreased levels of HDL (High Density Lipoprotein). This study to find out differences in triglyceride and HDL levels in pharmacist before and after night shift in Apotek Indobat Denpasar. This study method is preexperimental one group pretest-posttest design. Blood collection was carried out on 28 pharmacists before and after the night shift. Triglyceride levels were measured using the GPO-PAP (Glycerol Peroxidase Phosphate Acid) method and HDL measured using the CHOD-PAP (Cholesterol Oxidase Diaminase Peroxidase Aminoantipyrine) method with a chemistry analyzer. The average triglyceride levels before the night shift were $87.05 \pm 0.53 \mathrm{mg} / \mathrm{dL}$, and levels after the night shift were $105.77 \pm 0.50 \mathrm{mg} / \mathrm{dL}$ with a percentage increase in triglyceride levels was $24.66 \%$. The average HDL levels before the night shift were $59.84 \pm 0.47 \mathrm{mg} / \mathrm{dL}$, and the levels after the night shift were $48.61 \pm 0.42 \mathrm{mg} / \mathrm{dL}$ with a percentage decrease in HDL levels was $27.24 \%$. Based on the results of the study, the night shift can increase triglyceride levels and decrease HDL levels.
\end{abstract}

Keywords: chemistry analyzer, CHOD-PAP, HDL, GPO-PAP, pharmacist, triglycerides.

\section{PENDAHULUAN}

Tenaga kesehatan yang berkompetensi dan memiliki kualifikasi yang baik diperlukan untuk mencapai derajat kesehatan masyarakat yang setinggi-tingginya. Tenaga kesehatan menurut UU No. 36 Tahun 2009 adalah setiap orang yang mengabdikan diri dalam bidang kesehatan serta memiliki pengetahuan dan keterampilan melalui pendidikan di bidang kesehatan yang untuk jenis tertentu memerlukan kewenangan dalam melakukan upaya kesehatan. Salah satu tenaga kesehatan adalah tenaga kefarmasian, yaitu tenaga yang melakukan pekerjaan kefarmasian, yang terdiri dari apoteker dan tenaga teknis kefarmasian (PP RI Nomor 51 Tahun 2009). Tenaga kefarmasian memiliki tugas untuk mengelola obat, pelayanan obat atas resep dokter, pelayanan informasi obat kepada pasien dengan tujuan untuk meningkatkan 
kualitas hidup pasien (Permenkes RI No.

73 Tahun 2016).

Dalam rangka memaksimalkan produktivitas kerja dan menambah durasi pelayanan, tenaga kefarmasian membutuhkan sistem kerja yang diatur dalam suatu shift kerja. Kerja shift (rotasi secara bergilir) merupakan suatu cara dimana waktu kerja dibagi ke dalam shift secara bergantian pada tempat kerja yang sama (Ibrahim, 2010). Secara umum, shift kerja terdiri dari 3 shift, yaitu shift pagi (pukul 07.0014.00), shift sore (pukul 14.00-21.00), dan shift malam (pukul 21.00-07.00) (Mufidah, 2016). Bekerja dengan rotasi shift dimana pekerja bekerja berotasi pada pagi (7 jam), sore (7 jam), dan malam hari (10 jam) membuat pekerja lebih berisiko mengalami gangguan kesehatan, salah satunya adalah terganggunya irama sirkadian tubuh (Mufidah, 2016). Irama sirkadian merupakan dasar metabolisme, fisiologis, dan psikologis pada siklus tidur dan bangun harian. Irama sirkadian merupakan suatu istilah yang digunakan untuk menggambarkan pola hidup organisme setiap hari dan berlangsung sekitar 24 jam. Terganggunya irama sirkadian terjadi jika adanya perubahan jadwal kegiatan (tidur, makan, dan aktivitas lain) seperti pada pekerja shift, terutama shift malam (Noer dan Kirana, 2014).
Gangguan irama sirkadian (melalui perubahan siklus bangun dan tidur) diketahui memiliki hubungan dengan terjadinya peningkatan stres psikososial dan perubahan kebiasaan makan. Sebagai konsekuensi dari perubahan ini, seseorang dapat mengalami peningkatan berat badan (obesitas), tekanan darah tinggi yang tidak normal, kadar glukosa darah tinggi, serta gangguan lipogenesis (Farha and Eman, 2018). Selain itu, gangguan irama sirkadian dapat menyebabkan terganggunya waktu tidur dan hal tersebut berhubungan dengan keseimbangan kadar hormon, diantaranya adalah terjadinya penurunan hormon leptin (hormon penekan nafsu makan) dan peningkatan hormon ghrelin (hormon peningkat nafsu makan), dimana hal tersebut berkontribusi dalam peningkatan kadar lipid dalam darah (Lin et al, 2017).

Hal tersebut sesuai dengan penelitian Alefishat and Abu (2015) menunjukkan bahwa kadar trigliserida mengalami peningkatan dan kadar HDL mengalami penurunan pada pekerja shift malam. Penelitian lain oleh Vaithialingam et al (2014) menunjukkan bahwa kadar trigliserida lebih tinggi daripada kadar kolesterol pada pekerja shift malam (rata-rata 206,33 mg/dL) dan kadar HDL mengalami penurunan pada pekerja shift malam (rata-rata $46,40 \mathrm{mg} / \mathrm{dL}$ ). Penelitian lain yang 
dilakukan oleh Gadallah et al (2017) menunjukkan bahwa kadar trigliserida mengalami peningkatan pada pekerja shift malam (59,3\%) dibandingkan dengan pekerja non shift malam $(31,2 \%)$, sementara kadar HDL mengalami penurunan pada pekerja shift malam $(30,2 \%)$ dibandingkan dengan pekerja non shift malam $(6,2 \%)$.

Penelitian yang telah dilakukan menunjukkan bahwa bekerja dalam sistem shift merupakan salah satu faktor risiko yang dapat menyebabkan terjadinya peningkatan kadar lipid, terutama pekerja shift malam (Gadallah, 2017). Oleh karena itu, para pekerja shift malam perlu melakukan suatu screening profil lipid, salah satunya adalah trigliserida dan HDL. Screening tersebut dilakukan untuk mengetahui seberapa besar kadar trigliserida dan HDL dalam darah dan juga sebagai upaya untuk mencegah timbulnya penyakit yang dapat diakibatkan oleh karena peningkatan kadar lipid diantaranya adalah obesitas, dislipidemia, aterosklerosis, dan penyakit kardiovaskular (Medscape, 2018).

Oleh karena itu, penelitian ini dilakukan untuk mengetahui perbedaan kadar trigliserida dan HDL (High Density Lipoprotein) pada tenaga farmasi sebelum dan sesudah shift malam di Apotek Indobat Denpasar.

\section{METODE PENELITIAN}

Jenis penelitian ini adalah preexperimental one group pretest-posttest design dan telah dilakukan pada bulan Desember 2018-Januari 2019 di 7 Apotek Indobat Denpasar (Padangsambian, Teuku Umar, Tukad Buaji, Yeh Aya, Pakerisan, Sidakarya, Pemogan) dan analisis kadar trigliserida dan HDL dilakukan di Niki Diagnostic Center Denpasar. Sampel penelitian ini adalah 28 tenaga farmasi yang bekerja shift malam di Apotek Indobat Denpasar, dengan teknik sampling yang digunakan adalah total sampling.

Alat yang digunakan dalam penelitian ini adalah jarum vakutainer dan holder (BD Vacutainer), tourniquet, kapas alkohol 70\% (Oneswab), plester, tabung tutup kuning, cool box, ice gel, alat chemistry analyzer (Thermo), centrifuge (Eppendorf), mikropipet (Eppendorf), tip, dan lembar kuesioner. Bahan yang digunakan dalam penelitian ini adalah serum, dan reagen trigliserida dan reagen HDL (Thermo)

Pemberian Informed Consent dan Kuesioner

Pemberian informed consent dan kuesioner dilakukan sebelum pengambilan sampel darah, disertai dengan pemberian informasi mengenai puasa yang harus dilakukan selama 10 jam sebelum pengambilan sampel darah. 
Pemeriksaan Trigliserida dan HDL dengan Chemistry Analyzer

Pengambilan darah vena dilakukan sebanyak 2 kali, yaitu yang pertama dilakukan sebelum shift malam, yaitu 1 jam sebelum mulai shift malam, dan yang kedua dilakukan setelah shift malam kedua berakhir, yaitu pada pagi hari setelah lepas shift malam kedua. Sampel darah yang diperoleh diberi label identitas pada tabung vakum. Darah yang telah didapat ditunggu hingga membeku. Setelah itu, dimasukkan ke dalam centrifuge untuk dilakukan pemisahan dengan posisi tabung diatur dalam keadaan seimbang dan diputar dengan kecepatan 3000 rpm selama 15 menit. Serum yang terbentuk kemudian dipisahkan dari darah untuk dilakukan pemeriksaan.

Pemeriksaan trigliserida dan HDL dilakukan dengan menggunakan alat chemistry analyzer dengan merek Thermo dan dibaca pada panjang gelombang $510 \quad \mathrm{~nm}$. Prosedur pemeriksaan dimulai dari pemipetan serum sebanyak $400 \mu \mathrm{L}$ dan dimasukkan ke dalam wadah sampel. Setelah itu, diinput data pasien ke dalam komputer, dipilih jenis pemeriksaan trigliserida dan HDL, kemudian disimpan data yang telah diinput. Selanjutnya, serum yang sudah berada di dalam wadah serum dimasukkan ke dalam rak sampel dan diletakkan ke dalam alat. Kemudian alat memproses pemeriksaan dan ditunggu hasil keluar.

Teknik analisa data yang digunakan adalah uji statistik non parametrik berupa uji komparatif 2 sampel berpasangan menggunakan uji Wilcoxon untuk melihat ada tidaknya perbedaan dari 2 data sampel yang berpasangan. Data yang diperoleh dari kuesioner disajikan dalam bentuk tabel dan dilakukan penjabaran karakteristik responden.

\section{HASIL PENELITIAN}

Hasil karakteristik responden tenaga farmasi di apotek Indobat dibedakan menjadi beberapa parameter, yaitu usia, jenis kelamin, BMI (Body Mass Index), gaya hidup (meliputi pola makan, merokok, konsumsi alkohol, dan olahraga), waktu tidur dan riwayat penyakit dan disajikan pada Tabel 1 berikut. 


\section{The Joumal Of Muhammadiyah Medical Laboratory Technologist \\ Vol.2 No.2, Mei2019 \\ p-SSN: 2597-3681 e-ISSN:26142805}

\begin{tabular}{|c|c|c|c|}
\hline No. & \multicolumn{2}{|c|}{ Parameter kuesioner } & Jumlah \\
\hline \multirow{3}{*}{1.} & \multirow{3}{*}{ Usia } & $<20$ tahun & 5 orang \\
\hline & & 20-30 tahun & 20 orang \\
\hline & & $>30$ tahun & 3 orang \\
\hline \multirow{2}{*}{2.} & \multirow{2}{*}{ Jenis kelamin } & Laki-laki & 19 orang \\
\hline & & Perempuan & 9 orang \\
\hline \multirow{4}{*}{3.} & \multirow{4}{*}{$\begin{array}{c}\text { BMI (Body Mass } \\
\text { Index) }\end{array}$} & Kurang & 3 orang \\
\hline & & Normal & 19 orang \\
\hline & & Berlebih & 6 orang \\
\hline & & Obesitas & - \\
\hline \multirow{2}{*}{4.} & \multirow{2}{*}{ Pola makan } & Sehat & 27 orang \\
\hline & & Tidak sehat & 1 orang \\
\hline \multirow{3}{*}{5.} & \multirow{3}{*}{ Waktu tidur } & $<6$ jam & 28 orang \\
\hline & & 6-7 jam & - \\
\hline & & $>7 \mathrm{jam}$ & - \\
\hline \multirow{2}{*}{6.} & \multirow{2}{*}{ Merokok } & Iya & 6 orang \\
\hline & & Tidak & 22 orang \\
\hline \multirow{2}{*}{7.} & \multirow{2}{*}{ Minuman beralkohol } & Konsumsi & - \\
\hline & & Tidak konsumsi & 28 orang \\
\hline \multirow{3}{*}{8.} & \multirow{3}{*}{ Olahraga } & Sering & 3 orang \\
\hline & & Jarang & 5 orang \\
\hline & & Tidak pernah & 20 orang \\
\hline \multirow{2}{*}{9.} & \multirow{2}{*}{ Riwayat penyakit } & Ada & - \\
\hline & & Tidak ada & 28 orang \\
\hline
\end{tabular}

Berdasarkan tabel diatas, sebanyak 28 tenaga farmasi di apotek Indobat Denpasar bersedia menjadi sampel penelitian. Dari 28 tenaga farmasi, 5 orang berusia $<20$ tahun, 20 orang berusia $20-30$ tahun, dan 3 orang berusia > 30 tahun. Dari 28 tenaga farmasi, 19 orang berjenis kelamin laki-laki dan 9 orang berjenis kelamin perempuan. Dari 28 tenaga farmasi, 3 orang memiliki BMI kurang, 19 orang memiliki BMI normal, dan 6 orang memiliki BMI berlebih. Dari 28 tenaga farmasi, 27 orang memiliki pola makan sehat, dan 1 orang memiliki pola makan tidak sehat. Dari 28 tenaga farmasi, 28 orang memiliki waktu tidur selama shift malam $<6$ jam. Dari 28 tenaga farmasi, 6 orang merokok, dan 22 orang tidak merokok. Dari 28 tenaga farmasi, 28 orang tidak mengonsumsi minuman beralkohol. Dari 28 tenaga farmasi, 3 orang sering berolahraga, 5 orang jarang berolahraga, dan 20 orang tidak pernah berolahraga. Dari 28 tenaga farmasi, 28 orang tidak memiliki riwayat penyakit.

Pemeriksaan kadar trigliserida pada 28 tenaga farmasi dilakukan sebelum dan sesudah shift malam. Hasil pemeriksaan trigliserida disajikan pada Tabel 2 berikut 
Tabel 2. Hasil Pemeriksaan Trigliserida Pada Tenaga Farmasi di Apotek Indobat Denpasar

\begin{tabular}{cccc}
\hline \multirow{2}{*}{ No. } & \multirow{2}{*}{ Apotek Indobat } & \multicolumn{2}{c}{ Kadar trigliserida $(\mathbf{m g} / \mathbf{d L})$} \\
\cline { 2 - 4 } & & Sebelum & Sesudah \\
\hline 1. & Padangsambian & $77,17 \pm 0,48$ & $73,61 \pm 0,48$ \\
2. & Teuku Umar & $104,50 \pm 0,72$ & $127,92 \pm 0,58$ \\
3. & Tukad Buaji & $83,17 \pm 0,58$ & $110,75 \pm 0,44$ \\
4. & Yeh Aya & $72,40 \pm 0,46$ & $80,93 \pm 0,58$ \\
5. & Pakerisan & $93,75 \pm 0,58$ & $118,50 \pm 0,29$ \\
6. & Sidakarya & $95,67 \pm 0,58$ & $113,00 \pm 0,58$ \\
7. & Pemogan & $82,67 \pm 0,29$ & $115,67 \pm 0,58$ \\
& Rata-rata & $\mathbf{8 7 , 0 5} \pm \mathbf{0 , 5 3}$ & $\mathbf{1 0 5 , 7 7} \pm \mathbf{0 , 5 0}$ \\
\hline
\end{tabular}

Berdasarkan tabel diatas, rata-rata kadar trigliserida pada tenaga farmasi di Apotek Indobat sebelum shift malam tertinggi sebesar $104,50 \pm 0,72 \mathrm{mg} / \mathrm{dL}$, kadar terendah

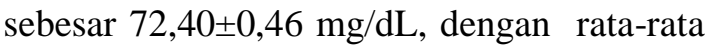
sebesar $87,05 \pm 0,53 \mathrm{mg} / \mathrm{dL}$. Hasil rata-rata kadar trigliserida pada tenaga farmasi di
Apotek Indobat sesudah shift malam tertinggi sebesar $127,92 \pm 0,58 \mathrm{mg} / \mathrm{dL}$, kadar terendah sebesar 73,61 $\pm 0,48 \mathrm{mg} / \mathrm{dL}$, dengan rata-rata sebesar $105,77 \pm 0,50 \mathrm{mg} / \mathrm{dL}$.

Hasil persentase kenaikan kadar trigliserida disajikan pada Tabel 3 berikut.

Tabel 3. Persentase Kenaikan Kadar Trigliserida

\begin{tabular}{ccc}
\hline No. & Apotek Indobat & $\begin{array}{c}\text { \% kenaikan kadar } \\
\text { trigliserida }\end{array}$ \\
\hline 1. & Padangsambian & $10,39 \%$ \\
2. & Teuku Umar & $28,37 \%$ \\
3. & Tukad Buaji & $39,67 \%$ \\
4. & Yeh Aya & $13,79 \%$ \\
5. & Pakerisan & $14,19 \%$ \\
6. & Sidakarya & $18,84 \%$ \\
7. & Pemogan & $47,37 \%$ \\
& Rata-rata & $\mathbf{2 4 , 6 6 \%}$ \\
\hline
\end{tabular}

Berdasarkan tabel diatas, persentase kenaikan kadar trigliserida di Apotek Indobat tertinggi sebesar 47,37\%, kadar terendah sebesar $10,39 \%$, dan kadar rata-rata sebesar $24,66 \%$.

Pemeriksaan kadar HDL pada 28 tenaga farmasi dilakukan sebelum dan sesudah shift malam. Hasil pemeriksaan HDL disajikan pada Tabel 4 berikut. 
Tabel 4. Hasil Pemeriksaan HDL Pada Tenaga Farmasi di Apotek Indoat Denpasar

\begin{tabular}{cccc}
\hline \multirow{2}{*}{ No. } & Apotek Indobat & \multicolumn{2}{c}{ Kadar HDL (mg/dL) } \\
\cline { 3 - 4 } & & Sebelum & Sesudah \\
\hline 1. & Padangsambian & $56,62 \pm 0,48$ & $50,06 \pm 0,39$ \\
2. & Teuku Umar & $51,00 \pm 0,58$ & $46,34 \pm 0,58$ \\
3. & Tukad Buaji & $55,59 \pm 0,44$ & $56,42 \pm 0,44$ \\
4. & Yeh Aya & $67,34 \pm 0,35$ & $58,14 \pm 0,46$ \\
5. & Pakerisan & $59,42 \pm 0,44$ & $44,34 \pm 0,44$ \\
6. & Sidakarya & $52,78 \pm 0,39$ & $39,45 \pm 0,39$ \\
7. & Pemogan & $76,17 \pm 0,58$ & $45,51 \pm 0,58$ \\
& Rata-rata & $\mathbf{5 9 , 8 4} \pm \mathbf{0 , 4 7}$ & $\mathbf{4 8 , 6 1 \pm 0 , 4 2}$ \\
\hline
\end{tabular}

Berdasarkan tabel diatas, rata-rata kadar HDL pada tenaga farmasi di Apotek Indobat sebelum shift malam tertinggi sebesar $76,17 \pm 0,58 \mathrm{mg} / \mathrm{dL}$, kadar terendah sebesar $51,00 \pm 0,58 \mathrm{mg} / \mathrm{dL}$, dengan rata-rata sebesar $59,84 \pm 0,47 \mathrm{mg} / \mathrm{dL}$. Hasil rata-rata kadar HDL pada tenaga farmasi di Apotek Indobat sesudah shift malam tertinggi sebesar $58,14 \pm 0,46 \mathrm{mg} / \mathrm{dL}$, kadar terendah sebesar $39,45 \pm 0,39 \mathrm{mg} / \mathrm{dL}$, dengan rata-rata sebesar $48,61 \pm 0,42 \mathrm{mg} / \mathrm{dL}$.

Hasil persentase penurunan kadar HDL disajikan pada Tabel 5 berikut.

Tabel 5. Persentase Penurunan Kadar HDL

\begin{tabular}{ccc}
\hline No. & Apotek Indobat & \% penurunan kadar HDL \\
\hline 1. & Padangsambian & $20,27 \%$ \\
2. & Teuku Umar & $11,49 \%$ \\
3. & Tukad Buaji & $6,22 \%$ \\
4. & Yeh Aya & $17,85 \%$ \\
5. & Pakerisan & $32,22 \%$ \\
6. & Sidakarya & $34,58 \%$ \\
7. & Pemogan & $68,02 \%$ \\
& Rata-rata & $\mathbf{2 7 , 2 4 \%}$ \\
\hline
\end{tabular}


Berdasarkan tabel diatas, persentase kenaikan kadar HDL di Apotek Indobat tertinggi sebesar $68,02 \%$, kadar terendah sebesar $6,22 \%$, dan kadar rata-rata sebesar $27,24 \%$.

\section{PEMBAHASAN}

Pemeriksaan kadar trigliserida dan HDL pada 28 tenaga farmasi dilakukan sebelum dan sesudah shift malam di Apotek Indobat Denpasar. Hasil pemeriksaan menunjukkan bahwa ada perbedaan kadar trigliserida (dengan persentase kenaikan kadar trigliserida sebesar 24,66\%) dan HDL (dengan persentase penurunan kadar HDL sebesar 27,24\%) pada tenaga farmasi sebelum dan sesudah shift malam. Hasil uji statistik perbedaan kadar trigliserida pada tenaga farmasi sebelum dan sesudah shift malam menggunakan uji Wilcoxon memberikan hasil sebesar -3,371 dengan probabilitas sebesar 0,001. Hal ini berarti probabilitas < level of significance $(\alpha=5 \%)$. Dengan demikian dapat dinyatakan bahwa ada perbedaan yang signifikan kadar trigliserida sebelum dan sesudah shift malam di apotek Indobat Denpasar. Sementara itu, pengujian perbedaan kadar HDL pada tenaga farmasi sebelum dan sesudah shift malam menggunakan uji Wilcoxon memberikan hasil sebesar -3.473 dengan probabilitas sebesar 0.001. Hal ini berarti probabilitas < level of significance $(\alpha=5 \%)$. Dengan demikian dapat dinyatakan bahwa ada perbedaan yang signifikan kadar HDL pada tenaga farmasi sebelum dan sesudah shift malam di Apotek Indobat Denpasar.

Adanya perbedaan kadar trigliserida sebelum dan sesudah shift malam sesuai dengan penelitian yang dilakukan oleh Vaithialingam et al (2014), Gadallah et al (2017), Maleki et al (2018), Alefishat and Abu (2015), dan Romon et al (2008) yang menyatakan bahwa pekerja shift malam memiliki kadar trigliserida yang lebih tinggi. Adanya perbedaan kadar HDL sebelum dan sesudah shift malam sesuai dengan penelitian yang dilakukan oleh Vaithialingam et al (2014), Gadallah et al (2017), Alefishat and Abu (2015), dan Lin et al (2017) yang menyatakan bahwa pekerja shift malam memiliki kadar HDL yang rendah.

Terjadinya peningkatan kadar trigliserida dan penurunan kadar HDL pada shift malam disebabkan oleh terganggunya irama sirkadian tubuh akibat waktu tidur yang terganggu selama shift malam sehingga berpengaruh terhadap peningkatan stres psikososial dan perubahan kebiasaan makan (Farha and Eman, 2018), serta keseimbangan hormon yang terganggu, diantaranya adalah peningkatan hormon ghrelin (hormon peningkat nafsu makan) dan penurunan hormon leptin (hormon penekan nafsu makan) (Lin et al, 2017). Selain itu, terdapat faktor-faktor lain yang juga dapat berpengaruh terhadap terjadinya peningkatan kadar trigliserida dan penurunan kadar HDL, yaitu pola makan, kebiasaan merokok dan konsumsi alkohol, dan aktivitas fisik atau 
olahraga. Terjadinya peningkatan kadar trigliserida dan penurunan kadar HDL dapat menimbulkan risiko terhadap gangguan kesehatan, diantaranya obesitas (Sang, 2013), dislipidemia (Gadallah et al, 2017), aterosklerosis, dan penyakit kardiovaskular (Vaithialingam et al, 2014).

\section{KESIMPULAN}

Berdasarkan hasil penelitian analisis kadar trigliserida dan HDL (High Density Lipoprotein) pada tenaga farmasi di apotek Indobat Denpasar dapat disimpulkan bahwa :

1. Pada penelitian ini terdapat perbedaan kadar trigliserida tenaga farmasi sebelum dan sesudah shift malam, dimana kadar trigliserida sesudah shift malam lebih tinggi dibandingkan dengan kadar sebelum shift malam, dengan persentase kenaikan kadar trigliserida sebesar $24,66 \%$.

2. Pada penelitian ini terdapat perbedaan kadar HDL (High Density Lipoprotein) pada tenaga farmasi sebelum dan sesudah shift malam, dimana kadar HDL sebelum shift malam lebih tinggi dibandingkan dengan kadar setelah shift malam, dengan persentase penurunan kadar HDL sebesar $27,24 \%$.

\section{SARAN}

Saran yang dapat disampaikan pada penelitian ini adalah perlunya penambahan parameter pemeriksaan profil lipid yang berbeda dan waktu pengukuran shift malam yang diperpanjang.

\section{DAFTAR PUSTAKA}

Alefishat, E. and Abu F. 2015. Is Shift Work Associated with Lipid Disturbances and Increased Insulin Resistance? Metab Syndr Relat Disord Vol. 13 No. 9.

Farha, R.A. and Eman A. 2018. Shift Work and the Risk of Cardiovascular Diseases and Metabolic Syndrome Among Jordanian Employees. Oman Medical Journal Vol. 33 No. 3.

Gadallah, M. et al. 2017. Association of Rotating Night Shift With Lipid Profile Among Nurses in an Egyptian Tertiary University Hospital. Eastern Mediterranean Health Journal Vol. 23 No. 4.

Ibrahim. 2010. Kadar Hormon Catecholamin dan Cortisol Urin Pada Perawat yang Bekerja Shift. Jurnal Kedokteran Yarsi Vol. 18 No. 1.

Lin, P. et al. 2017. Association Between Self-Reported Sleep Duration and Serum Lipid Profile in a MiddleAged and Elderly Population in Taiwan : A Community-Based, Cross-Sectional Study. BMJ Open 2017.

Maleki, S. et al. 2018. The Moderating Effect of Shift Work on Lipid Pathway: An Application of Multi-Group Path Analysis 
p-ISSN: 2597-3681 e-ISSN:26142805

Model. Iran Red Crescent Med J Permenkes RI No. 73 Tahun 2016 Vol. 20 No. 9.

Tentang Standar Pelayanan Kefarmasian di Apotek.

Medscape. 2018. Hypertriglyceridemia Treatment \& Management. Article on emedicine.medscape.com.

PP Republik Indonesia No. 51 Tahun 2009 Tentang Pekerjaan Kefarmasian.

Mufidah, Z. 2016. Perbedaan Kadar Glukosa Darah Puasa Antara Bidan yang Bekerja Shift dan Non Shift di RSUD Dr. Soetomo Surabaya. Skripsi. Universitas Airlangga Surabaya.

Noer, E.R., Kirana L. 2014. Peningkatan Angka Kejadian Obesitas dan Hipertensi Pada Pekerja Shift. Journal Nutrition of Health Vol. 2 No. 1.

Romon, M. et al. 2008. Increased Triglyceride Levels in Shift Workers. AMJ Med Vol. 93 No. 3.

Sang, B.K. 2013. Night Shift Work, Sleep Quality, and Obesity. Journal of Lifestyle Medicine Vol. 3 No. 2.

Vaithialingam, et al. 2014. Shift Medical Worker in Medical College and Hospitals. Research Journal of Pharmaceutical, Biological and Chemical Vol. 5 No. 3. 